\title{
Evidence for selective estrogen receptor modulator activity in a black cohosh (Cimicifuga racemosa) extract: comparison with estradiol-17 $\beta$
}

\author{
Dana Seidlová-Wuttke, Oda Hesse, Hubertus Jarry, Volker Christoffel ${ }^{1}$, Barbara Spengler ${ }^{1}$, Tamara Becker and
} Wolfgang Wuttke

Department of Clinical and Experimental Endocrinology, University of Göttingen, Robert-Koch-Strasse 40, D-37075 Göttingen, Germany and ${ }^{1}$ Bionorica AG, Neumarkt, Germany

(Correspondence should be addressed to WWuttke; Email: ufkendo@med.uni-goettingen.de)

\begin{abstract}
Objective: Some phytoestrogens are believed to have selective estrogen receptor modulator (SERM) activity with no action in the uterus but beneficial effects in the hypothalamo/pituitary unit and in the bone and are presently the focus of clinical interest. In the present experiments, the effects of the clinically used Cimicifuga racemosa (CR) extract BNO 1055 in the uterus, in the bone and on serum luteinizing hormone $(\mathrm{LH})$ were compared with the effects of estradiol- $17 \beta\left(\mathrm{E}_{2}\right)$ under acute and chronic conditions in ovariectomized rats.

Methods: Ovariectomized rats were treated either acutely $(6 \mathrm{~h})$ or chronically (3 months) with $\mathrm{E}_{2}$ or the CR extract. Gene expression of some estrogen-regulated genes in the metaphysis of the tibia and the uterus was determined. Furthermore, bone mineral density was measured by quantitative computer tomography.

Results: When given acutely, both $\mathrm{E}_{2}$ and the CR extract inhibited LH secretion and slightly stimulated gene expression of IGF-I, collagen-1 $1 \alpha 1$, osteoprotegerin and osteocalcin (all osteoblast products), and of tartrate-resistant acid phosphatase (TRAP, an osteoclast product) in the metaphysis of the femur. While $\mathrm{E}_{2}$ stimulated uterine weight and expression of progesterone receptor (PR), the complement protein (C3) and IGF-I genes, and inhibited gene expression of the estrogen receptor $\beta$ (ER $\beta$ ) in the uterus, no such effect was observed under acute CR treatment. After chronic application with pelleted food over 3 months $E_{2}$ had profound effects in the uterus on weight and gene expression (ER $\beta, P R, C 3$ and IGF-I) which were not seen in the CR-treated animals. Within 3 months after ovariectomy, control rats had lost more than $50 \%$ of the metaphyseal bone mass of the tibia, an effect prevented by $E_{2}$ and partially by $\mathrm{CR}$ supplementation.

Conclusions: These data confirm the concept that the CR extract BNO 1055 contains as yet unidentified substances with SERM properties which act in the hypothalamo/pituitary unit and in the bone but not in the uterus.
\end{abstract}

European Journal of Endocrinology 149 351-362

\section{Introduction}

Estrogen receptors (ER) are present in almost all organs of the body. The two cloned ERs (ER $\alpha$ and ER $\beta)$ show characteristic distribution in the body (for review see 1) and they transmit estrogenic messages by acting as transcription factors on the estrogen response element (ERE) of a variety of estrogen-regulated genes (for review see 1). We have earlier shown that Cimicifuga racemosa (CR) extracts have estrogenic effects in the hypothalamo/pituitary unit to suppress pituitary luteinizing hormone (LH) secretion in ovariectomized rats but to lack an estrogenic, i.e. stimulatory effect on uterine weight (2). At this time an explanation for such organ-selective effects of the CR extract cannot be given. It is now well established that substances exist which have estrogenic effects in some organs but no or even anti-estrogenic effects in others. These substances are called selective estrogen receptor modulators (SERMs) (for review see 3). Our increasing knowledge about such SERM activities may now offer a plausible explanation for the organ-selective effects of the CR extract.

The pituitary LH-producing cells express gonadotropin-releasing hormone (GnRH) receptors which need to be exposed to the ligand - namely $\mathrm{GnRH}-$ in a pulsatile fashion (4). The neuronal network that causes pulsatile GnRH release is called the GnRH pulse generator. Following ovariectomy, the GnRH pulse generator becomes hyperactive which results in 
pulsatile LH secretion at a high rate with high LH pulse amplitudes. The overactivation of the GnRH pulse generator causes co-activation of other hypothalamic neurons which regulate body temperature and thereby vasodilation of skin vessels which are experienced as hot flushes in climacteric women (5). Estradiol substitution of ovariectomized rats dampens the overactivity of the GnRH pulse generator, thereby hot flushes are diminished or cease and pituitary LH secretion is reduced. Hence, this so-called negative feedback action of estrogens on pituitary LH secretion in ovariectomized rats can be used as an indirect measure of hot flushes.

The uterus is a highly sensitive target for estrogen action and this effect is primarily mediated via the ER of the $\alpha$-subtype $(1,6)$. When administered acutely, estradiol-17 $\beta\left(\mathrm{E}_{2}\right)$ causes an edematous swelling (uterine ballooning). Upon chronic administration, uterine tissue proliferates and the myometrium and endometrium become hypertrophic. Both acute and chronic effects of $E_{2}$ are in part due to activation of the insulin-like growth factor-I (IGF-I) gene and protein expression (for review see $1,7,8$ ). In addition, a protein belonging to the complement family (C3), the function of which is largely unknown, is dramatically stimulated by $E_{2}$ and some phytoestrogens (9).

The bone is also a target organ for estrogens. Both receptor subtypes have been demonstrated in the bones of immature rats and osteoblast cell lines $(10-13)$. Whether the bones of adult rats express both or only the ER $\alpha$ subtype is controversial (14, 15). It appears that it is primarily the osteoblast cell line that expresses the ER of the $\alpha$-subtype (10-12, 14). The dominant effect of $\mathrm{E}_{2}$ in these cells is to stimulate production of osteocalcin (OC) and collagen- $1 \alpha 1$, a bone-specific matrix protein (16). Also osteoprotegerin (OPG), a soluble receptor belonging to the tumor necrosis factor receptor family $(17,18)$, appears to be $E_{2}$ regulated $(19,20)$. The function of OPG is to bind and thereby to inactivate osteoclast differentiation factor. As a result, osteoclast differentiation and hence activity is inhibited (17-20). Many of these effects are mediated by a stimulation of osteoblast IGF-I production $(21,22)$. The question as to whether or not osteoclasts are estrogen receptive and, if so, which ER type is being expressed, is much less clear $(11,14,15)$. The effects of estrogens on tartrate-resistant acid phosphatase (TRAP), an osteoclast product, have been described which, however, could be indirectly exerted via paracrine mechanisms, through factors released by osteoblasts. In each case, $\mathrm{E}_{2}$ has osteoprotective effects in that it prevents the development of osteoporosis following ovariectomy. To estimate the bone mineral density of the proximal metaphysis of the tibia, computer-assisted tomography (CT) allowed determination of trabecular density of the metaphysis of the tibia. It is well documented that loss of estrogens results in increased fat accumulation in animals (23). In the same CT plane in which the tibial metaphysis was scanned a paratibial fat depot was visible, the surface of which could also be quantified. This allowed not only a functional estimate of the degree of osteoporosis developing during the course of the 3-month investigation period and whether or not $\mathrm{E}_{2}$ and the CR extract have osteoporosis-preventing effects but also an exact measurement of fat accumulation in this area.

The fact that, in earlier experiments, CR extracts had a negative feedback effect on $\mathrm{LH}$ secretion in the hypothalamo/pituitary unit but no effects on uterine weight (2) suggested to us that SERM activities are possibly present in the rhizome of this plant and prompted us to investigate the acute and chronic effects of the CR extract (BNO 1055) on serum LH levels and on the expression of the above-mentioned estrogenregulated genes in the uterus and bone.

\section{Materials and methods}

Female Sprague-Dawley rats were used for the present experiments. Permission to perform these experiments was obtained from the Landesregierung Braunschweig (permission no. Az. 509.42502/01-13.00 dated 17 July 2000). Upon arrival from the supplier (Winkelmann, Borchen, Germany) the rats were fed with pelleted chow in which soy proteins were replaced by potato proteins. One week after arrival they were ovariectomized. Food and water were available ad libitum. The animal quarters were illuminated from 0600 to $1800 \mathrm{~h}$. Room temperature was $25^{\circ} \mathrm{C}$ at a relative humidity of $55 \%$.

The CR extract was obtained from Bionorica (Neumarkt, Germany) and was an aqueous/ethanolic extract of the rhizomes of cultivated plants. The preparation of the CR extract BNO 1055 was as follows: finely ground $\mathrm{CR}$ rhizomes were extracted with five times the amount of $50 \%(\mathrm{v} / \mathrm{v})$ water/ethanol for $48 \mathrm{~h}$ with a percolation speed of $500 \mathrm{~kg} / \mathrm{h}$. After filtration, the extract was concentrated under vacuum and evaporated to dryness at 100-140 mbar according to a patent-protected process. The product temperature did not exceed $40^{\circ} \mathrm{C}$.

\section{Acute experiments}

Three to four weeks after ovariectomy the jugular vein of each animal was catheterized. After recovery for $24 \mathrm{~h}$, blood samples $(100 \mu \mathrm{l})$ were withdrawn starting at $0700 \mathrm{~h}$ at 10 -min intervals for $60 \mathrm{~min}$. Thereafter, $\mathrm{E}_{2} \quad(3.5 \mu \mathrm{g} / \mathrm{animal})$, the $\mathrm{CR}$ extract BNO 1055

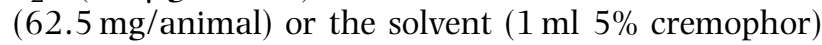
was slowly infused i.v. within 1 min. Further blood samples were withdrawn at 10-min intervals for the next 2 h. Six hours after i.v. injection of test substances the animals were decapitated, blood was collected from 
the trunk, the uteri were removed and weighed and the metaphysis of the femurs prepared. Both organ specimens were then immediately frozen in liquid nitrogen and stored at $-80^{\circ} \mathrm{C}$.

\section{Chronic experiments}

Two chronic experiments were performed in which animals remained either untreated or were treated with $\mathrm{E}_{2}$ or the $\mathrm{CR}$ extract BNO 1055 immediately after ovariectomy. From experience with the animals' food intake in the last 2 weeks prior to the beginning of the experiments it was known that the mean food intake of each animal was $20 \pm 2 \mathrm{~g}$. On this basis, $\mathrm{E}_{2}$ and the CR extract (BNO 1055) was added such that $20 \mathrm{~g}$ food contained either $1.0 \mathrm{mg} \mathrm{E}_{2}$ in experiment 1 , $0.5 \mathrm{mg} \mathrm{E}_{2}$ in experiment 2, 200 or $1000 \mathrm{mg}$ CR extract BNO 1055 in experiment 1, or 50 or $200 \mathrm{mg}$ CR extract BNO 1055 in experiment 2. Each group of animals consisted of $15-18$ or 12 rats in experiments 1 or 2 respectively.

\section{Further details about experiment 1}

Animals were weighed and vaginal smears taken once per week. After 3 months they were decapitated, blood was collected from the trunk, and the uteri were removed, cleaned and weighed. In addition, the metaphysis of the femur was prepared and both tisssue specimens frozen immediately in liquid nitrogen and stored at $-80^{\circ} \mathrm{C}$.

\section{Further details about experiment 2}

Animals were weighed and vaginal smears taken twice weekly. Prior to experimentation, 1 day after ovariectomy, 2, 4, 8, and 12 weeks after the onset of $E_{2}$ or CR-supplemented food animals were anesthetized (inhalation anesthesia with isoflurane) and the density of the metaphysis of the tibia was recorded by CT (24) (XCT Research SA+STRATEC Medizintechnik GmbH, Pforzheim, Germany).

\section{Extraction of RNA}

Immediately after decapitation of the animals, the uterus and femur were dissected and snap-frozen in liquid nitrogen within $3 \mathrm{~min}$ to minimize degradation of RNA. Samples were stored at $-70^{\circ} \mathrm{C}$ until RNA preparation.

Total RNA was extracted from the metaphysis of the distal part of the femur and the uterus. Tissue samples were chilled in liquid nitrogen and pulverized in a $5 \mathrm{ml}$ Teflon container with a tissue homogenizer (Micro-dismembrator; Braun, Melsungen, Germany). The RNeasy Mini Kit (Qiagen, Hilden, Germany) was used for further processing of the samples following the manufacturer's instructions. Tissue powder $(50 \mathrm{mg})$ was suspended in $600 \mu \mathrm{l}$ (uterus) or $300 \mu \mathrm{l}$ (femur) RT-lysis buffer and further homogenized by brief ultrasound sonication $(10 \mathrm{~s})$. The homogenates were applied onto QIA shredder columns (Qiagen, Hilden, Germany) and the eluates were subsequently loaded onto the extraction columns. Total RNA was eluted with $50 \mu \mathrm{l}$ diethylpyrocarbonate (DEPC)-treated water. To determine RNA concentrations, $5 \mu$ l RNA solution was diluted with $75 \mu \mathrm{l}$ water. Absorption was measured at 260 and $280 \mathrm{~nm}$ with a biophotometer (Eppendorf, Hamburg, Germany). Concentrations of the RNA solutions were adjusted to $50 \mathrm{ng} \mathrm{RNA} / \mu \mathrm{l}$ (uterus) or $15 \mathrm{ng} / \mu \mathrm{l}$ (femur) with DEPC-treated water and stored at $-70^{\circ} \mathrm{C}$ until further analysis.

\section{Reverse transcription}

The RT reaction was carried out with either $500 \mathrm{ng}$ total RNA/10 $\mu$ l (uterus) or $150 \mathrm{ng}$ total RNA/10 $\mu \mathrm{l}$ (femur). In addition, the reaction mixture contained $4 \mu \mathrm{l} 5 \times$ reaction buffer with $250 \mathrm{mM}$ Tris $-\mathrm{HCl}$, $375 \mathrm{mM} \mathrm{KCl}, 15 \mathrm{mM} \mathrm{MgCl}_{2}$ and $50 \mathrm{mM}$ dithiothreitol. The concentrations of random primers and deoxyNTPs were $100 \mathrm{ng}$ and $10 \mathrm{mM}$ respectively, in a volume of $1 \mu \mathrm{l}$ each. The mixture was completed with Superscript RNase $\mathrm{H}^{-}$reverse transcriptase $(1 \mu \mathrm{l}$ containing 200U) and $1 \mu \mathrm{l}$ ribonuclease inhibitor (1 U; Promega, Mannheim, Germany). The final volume was adjusted with DEPC-treated water to $20 \mu \mathrm{l}$. All reagents except the ribonuclease inhibitor were purchased from GibcoBRL (Karlsruhe, Germany). Reverse transcription was initiated by incubation of samples at $22^{\circ} \mathrm{C}$ for $10 \mathrm{~min}$ followed by the enzymatic reaction conducted at $42{ }^{\circ} \mathrm{C}$ for $50 \mathrm{~min}$. At the end of incubation, the samples were heated at $95^{\circ} \mathrm{C}$ for $10 \mathrm{~min}$ to inactivate the enzyme and denature RNA-cDNA hybrids.

\section{Real-time PCR}

Real-time PCR reactions were based on the $5^{\prime}$ nuclease assay (25) which was run on an ABI Prism 7700 Sequence Detection System (TaqMan; PE Applied Biosystems, Foster City, CA, USA). The sequences of primers and probes for the genes analyzed in the present study are summarized in Table 1. Primers and probes were chosen with the assistance of the Primer Express software (PE Applied Biosystems). Oligonucleotides were purchased from Eurogentec (Seraing, Belgium).

Each PCR run included six duplicate cDNA samples of defined concentrations to generate a standard curve (derived from the in vitro transcription described below), a no-template control and the respective sample cDNAs. Amplification reactions $(25 \mu \mathrm{l})$ contained $1 \times$ TaqMan Universal PCR Master Mix (PE Applied Biosystems), 50-900 nM of each primer (for details see Table 1), 175-225 nM probe and 
Table 1 Sequences of primers and probes analysed.

\begin{tabular}{|c|c|c|c|c|}
\hline Gene & Primers: forward and reverse & Probe (5'-FAM-3'TAMRA) & $\begin{array}{l}\text { Product } \\
\text { size }\end{array}$ & $\begin{array}{c}\text { Reference } \\
\text { (Accession no.) }\end{array}$ \\
\hline ER- $\alpha$ & $\begin{array}{l}\text { 5'-AAGCTGGCCTGACTCTGCAG-3' } \\
\text { 5'-GCAGGTCATAGAGAGGCACGA-3' }^{\prime}\end{array}$ & 5'-CGTCTGGCCCAGCTCCTCCTCATC-3' & $144 \mathrm{bp}$ & $\begin{array}{c}(26) \\
(X 61098)\end{array}$ \\
\hline$E R-\beta$ & $\begin{array}{l}\text { 5'-GAGGAGATACCACTCTTCGCAATC-3' } \\
5^{\prime} \text {-GGAGTATCTCTGTGTGAAGGCCAT-3' }\end{array}$ & 5'-CAGGGCATCTGTCACCGCGTTCAG-3' & $159 \mathrm{bp}$ & $\begin{array}{c}(27) \\
\text { (U57439) }\end{array}$ \\
\hline PR & $\begin{array}{l}\text { 5'-CTGGTTCCGCCACTCATCAA-3' } \\
\text { 5'TCAGGCTCATCCAGGAGTACTGA-3' }\end{array}$ & 5'-CCGACACTTCCAGCTCTTTGCTGACCA-3' & $229 \mathrm{bp}$ & $\begin{array}{c}(28) \\
(\mathrm{L} 16922)\end{array}$ \\
\hline |GF-I & $\begin{array}{l}\text { 5'-TGTCGTCTTCACATCTCTTCTACCTG- } 3^{\prime} \\
5^{\prime} \text {-CCACACACGAACTGAAGAGCGT-3' }\end{array}$ & 5'-TTACCAGCTCGGCCACAGCCGGAC-3' & $121 \mathrm{bp}$ & $\begin{array}{c}(29) \\
(X 04482)\end{array}$ \\
\hline C3 & $\begin{array}{l}\text { 5'-CTGTACGGCATAGGGATATCACG-3' } \\
\text { 5'-ATGCTGGCCTGACCTTCAAGA-3' }\end{array}$ & 5'-ATGCCATCCTCACAACACTTCCGCAG-3' & $199 \mathrm{bp}$ & $\begin{array}{c}(30) \\
(X 52477)\end{array}$ \\
\hline $\begin{array}{l}\text { Type I-procollagen } \\
\alpha \text { chain }\end{array}$ & $\begin{array}{l}\text { 5-'GGCGAAGGCAACAGTCGAT-3' } \\
\text { 5'-TCCATTCCGAATTCCTGGTCT-3' }\end{array}$ & 5'-TGCACGAGTCACACCGGAACTTGG-3' & $173 \mathrm{bp}$ & $\begin{array}{c}(31) \\
(Z 78279)\end{array}$ \\
\hline Osteoprotegerin & $\begin{array}{l}\text { 5'-CСTCTTTCTTTCTGCCTCTGATAGTC-3' } \\
\text { 5'-CCAAGTCTGCAACTCGAATCAAAT-3' }\end{array}$ & 5'-CGTATCAGGTGCACGAGCCTTATCCCA-3' & $150 \mathrm{bp}$ & $\begin{array}{c}(17) \\
(\cup 94330)\end{array}$ \\
\hline Osteocalcin & $\begin{array}{l}\text { 5'-CAAAGCCCAGCGACTCTGA-3' } \\
\text { 5'-AGGTAGCGCCGGAGTCTATTC-3' }\end{array}$ & 5'-CCTTCATGTCCAAGCAGGAGGGCAGT-3' & 85 bp & $\begin{array}{c}(32) \\
(\mathrm{M} 11777)\end{array}$ \\
\hline $\begin{array}{l}\text { Tartrate-resistant } \\
\text { acid phosphatase } \\
\text { type } 5\end{array}$ & $\begin{array}{l}\text { 5'-GATCACCTTGGCAATGTCTCG-3' } \\
5^{\prime} \text {-GGCTGACAAAGTCGTCGGAAT-3' }\end{array}$ & 5'-TGCCTACTCCAAGATCTCCAAGCGCTG-3' & $175 \mathrm{bp}$ & $\begin{array}{c}(33) \\
(\mathrm{M} 76110)\end{array}$ \\
\hline
\end{tabular}

PR, progesterone receptor. FAM, 6-carboxy-fluoroscein; TAMRA, 6-carboxy-tetramethyl-rhodamine.

2-4 $\mu \mathrm{l}$ cDNA. The cycling conditions were 2 min incubation at $50{ }^{\circ} \mathrm{C}$ for eliminating carryover PCR products by uracil DNA glycosylase treatment, $10 \mathrm{~min}$ at $95^{\circ} \mathrm{C}$ for activation of the AmpliTaq Gold DNA polymerase followed by 40 cycles of $95^{\circ} \mathrm{C}$ for $15 \mathrm{~s}$ and $60^{\circ} \mathrm{C}$ for 1 min.

To generate cRNA, each PCR product was cloned into the pCR II-TOPO plasmid using the TOPO TA Cloning Kit following the manufacturer's instructions (Invitrogen, Groningen, The Netherlands). After confirming the sequence and orientation of the cloned PCR product by commercial sequencing (Seqlab, Göttingen, Germany), the plasmid construct was linearized with an appropriate restriction endonuclease and purified using the Wizard DNA Clean-Up System (Promega). RNA was synthesized according to the manufacturer's instructions using the RiboMAX Large Scale RNA Production System with either SP6or T7-polymerase respectively (Promega). After photometric determination of concentrations of the RNA stock solutions, serial dilutions (tenfold intervals) of the RNA were reverse transcribed as described above. The standard curve was generated by plotting the known cDNA concentrations versus the corresponding threshold cycle $\left(C_{t}\right)$ value obtained in the real-time PCR reaction using Sequence Detection Software (PE Applied Biosystems). To determine the relative expression levels of the tissue samples, the respective $\mathrm{C}_{\mathrm{t}}$ values were interpolated from the standard curve.

\section{LH radioimmunoassay}

The blood samples collected from animals in the acute or the chronic experiments were centrifuged $(3000 \boldsymbol{g}$,
$10 \mathrm{~min}$ ) and the serum used for measurement of $\mathrm{LH}$ by a specific radioimmunoassay supplied by the NHPP (Dr A F Parlow, Harbor-UCLA Medical Center, Torrance, CA, USA).

\section{CT analysis}

Measurement of bone density by CT yielded metaphyseal bone densities given in $\mathrm{mg} / \mathrm{cm}^{3}$ (24). The means of the controls at each measured time-point were calculated and set at $100 \%$. Each individual value of the treatment groups was \% related to this $100 \%$ value and the resulting means were compared statistically. In the CT scan of the metaphysis of the femur, a paratibial fat depot was visible, the surface of which within the CT plane could easily be quantified by perimetry. The percentage of this fat depot surface in relation to the total surface of the $\mathrm{CT}$ plane at the height of the metaphysis of the tibia can be calculated as an exact measure of the size of this fat depot.

\section{Statistical evaluation}

In the present study relative changes of mRNA levels were analyzed by comparison between the control and treatment groups. Based on the $C_{t}$ values of the PCR reactions measured in the control group, an average expression level of the analyzed target gene was calculated from the standard curve, which was set at $100 \%$. Individual $C_{t}$ values in the treatment groups were transformed in relation to this average value of the control group.

Data are expressed as means \pm S.E.M. Significant differences between the control and treatment groups 
were analyzed by one-way ANOVA followed by Dunnett's post hoc test for multiple comparisons (Graph Pad; Prism, San Diego, CA, USA). P values $<0.05$ were considered significant.

\section{Results}

\section{Acute experiments}

Figure 1 shows mean serum LH levels prior to and within the $120 \mathrm{~min}$ after i.v. injection of $0.5 \mu \mathrm{g} \mathrm{E}_{2}$ (Fig. 1a), $62.5 \mathrm{mg} \mathrm{CR}$ extract (Fig. 1b) and $1 \mathrm{ml}$ solvent (Fig. 1c). Both $\mathrm{E}_{2}$ and the $\mathrm{CR}$ extract suppressed serum LH levels significantly. Figure 2 shows that the acute $\mathrm{E}_{2}$ injection largely increased uterine weight within $6 \mathrm{~h}$, an effect not seen in the CR-treated animals. Expression of uterine $\mathrm{ER} \alpha, \mathrm{ER} \beta$, IGF-I and $\mathrm{C} 3$ genes is shown in Fig. 3. While the acute $E_{2}$ treatment had a slight but significant suppressive effect on ER $\alpha$ (Fig. 3a), it strongly downregulated the expression of the ER $\beta$ gene (Fig. 3b). Gene expression of IGF-I and C3 was largely upregulated by $\mathrm{E}_{2}$ (Fig. $\left.3 \mathrm{c}, \mathrm{d}\right)$. All parameters remained unaffected by the CR extract.

The acute effects of $E_{2}$ and $C R$ on the expression of a variety of genes in the metaphysis of the femur are shown in Fig. 4. While the concentrations of ER $\alpha$ (data not shown) and OPG mRNA were not affected by $E_{2}$ or CR, expression of the IGF-I and the collagen$1 \alpha 1$ gene were stimulated by $E_{2}$ and by the CR extract, though these effects were statistically not significant. Gene expression of TRAP was significantly stimulated by the CR extract, an effect also seen in the $E_{2}$-treated animals.

\section{Chronic experiments}

Similarly, under chronic conditions (3-month treatment in experiment 1) uterine weights (Fig. 5a) were significantly higher in the $\mathrm{E}_{2}$-treated animals in comparison with controls while the CR extract at two doses had no effect. Body weights (Fig. 5b) were significantly lower in the $\mathrm{E}_{2}$-treated animals in comparison with the controls, an effect also exerted by the higher CR $(1000 \mathrm{mg} / \mathrm{kg})$ but not by the lower $(200 \mathrm{mg} / \mathrm{kg})$ dose. The stimulating effect of $\mathrm{E}_{2}$ on uterine weight was due to stimulation of the thickness of both the endometrium and the myometrium (Fig. 6). Neither endometrial nor myometrial thickness or histological appearance (data not shown) were affected by the two concentrations of the CR extract.

Figure 7 shows that also under chronic conditions (in experiment 1), $E_{2}$ had no uterine effect on $\mathrm{ER} \alpha$ but suppressed ER $\beta$ and stimulated PR (though not significantly) gene expression, an effect not seen in the animals treated either with low or high amounts of the CR extract. Expression of the IGF-I and C3 genes in the uterus (Fig. 7) was, as under acute treatment conditions, largely stimulated in the $E_{2}$-treated

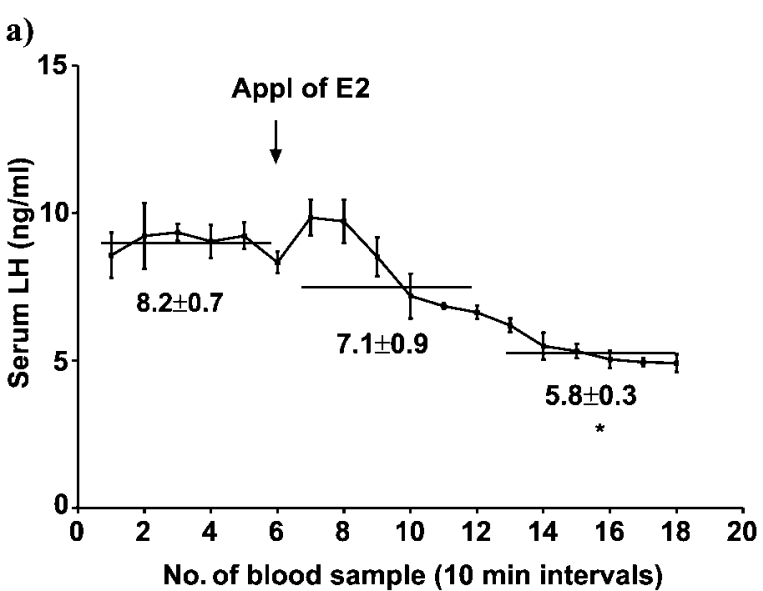

b)
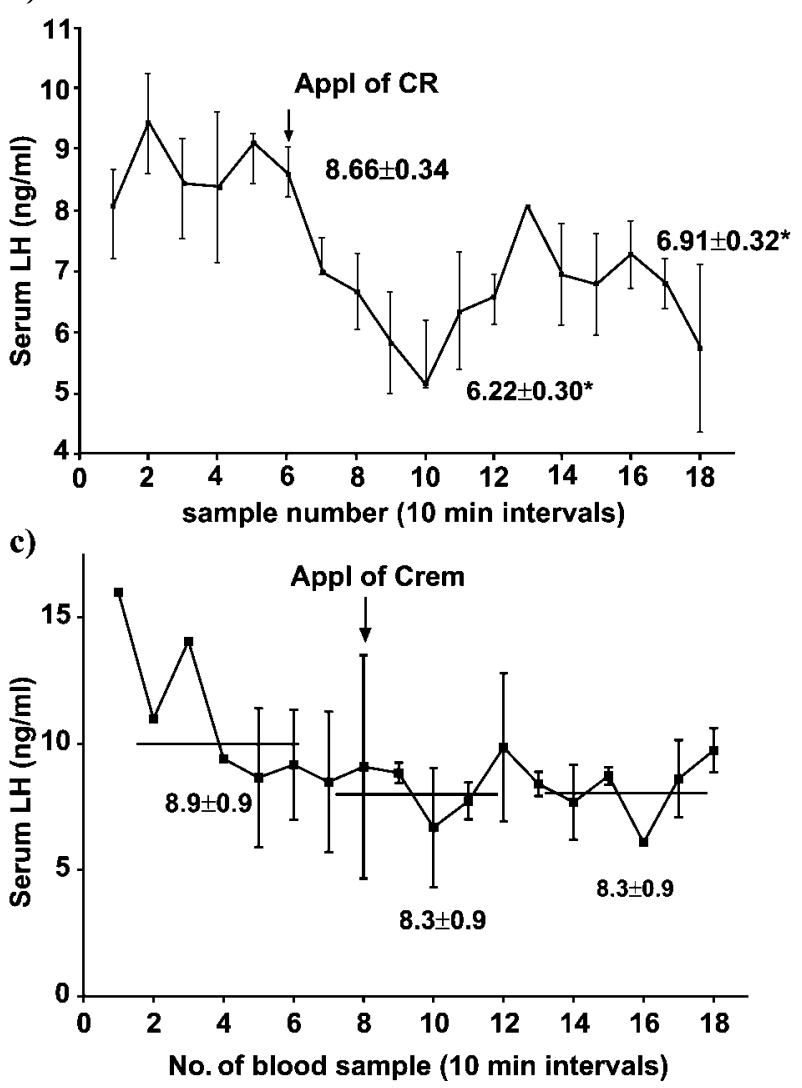

Figure 1 Effects of (a) $0.5 \mu \mathrm{g} \mathrm{E}_{2}$, (b) $62.5 \mathrm{mg} \mathrm{CR}$ extract and (c) solvent $(5 \%$ cremophor $=$ Crem) on serum LH levels before and after acute i.v. injection of the compounds. For statistical reasons mean $\mathrm{LH}$ levels in the hour before and for 1 and $2 \mathrm{~h}$ after injection of the compounds were calculated. They are shown as horizontal bars in each figure and the absolute values \pm S.E.M. are also given. ${ }^{\star} P<0.05$ vs pretreatment values.

animals. Neither the low nor the high amounts of CR fed to the animals had any significant effects on these uterine parameters (Fig. 7).

The chronic effects of E2 and the CR extract in the metaphysis of the femur were in striking contrast 


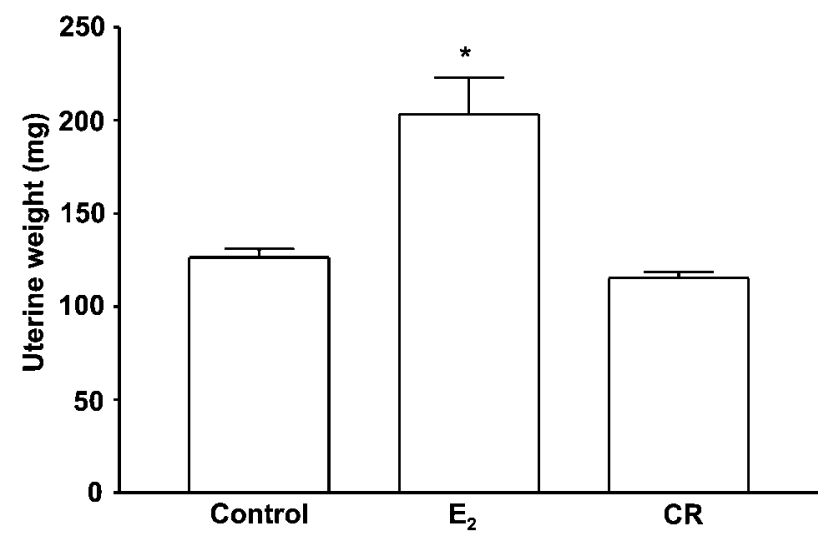

Figure 2 An acute i.v. injection of $E_{2}$, the $C R$ extract or the solvent resulted in stimulated uterine weight only by $E_{2}$ while the $\mathrm{CR}$ extract was totally ineffective. ${ }^{\star} P<0.05$ vs control.

to those seen under acute administration (Fig. 8). The expression of the marker genes for both osteoblast and osteoclast activity (collagen- $1 \alpha 1$, OPG, OC and TRAP respectively) were reduced by $\mathrm{E}_{2}$ and the higher dose of the CR extract. As under acute conditions, expression of the $\mathrm{ER} \alpha$ gene remained unaffected (data not shown). In none of the metaphyses of the femur was expression of the ER $\beta$ gene demonstrable (data not shown).

Figure 9 shows the CT-calculated bone densities of the metaphysis of the tibiae which were determined in the second chronic experiment. Animals receiving unsupplemented food lost $53.7 \%$ of their metaphysial bone density. This effect was statistically significantly reduced to $38.7 \%$ by the higher dose of the CR extract. The CR-treated animals lost more metaphysial bone density in comparison with the $\mathrm{E}_{2}$-treated animals but had significantly higher bone density than the unsupplemented controls.

Figure 10 shows the size of the paratibial fat depot in the untreated animals. The fat depot had doubled in size in comparison with the preovariectomy value. This effect was significantly reduced by $E_{2}$ and by both doses of the CR extract.

\section{Discussion}

In earlier experiments we had shown that the CR extract BNO 1055 was able to displace radiolabeled $\mathrm{E}_{2}$ from a cytosolic ER preparation (34). The main new observation made in the present study is that this (these) yet unidentified substance(s) have estrogenic effects not only in the hypothalamo/pituitary axis to reduce serum LH levels but also in the bone where they (it) mimick(s) both acute and chronic effects of $E_{2}$. In agreement with earlier observations, the CR extract at neither dosage had any significant estrogenic effect in the uterus (2). The acute and chronic effects of $E_{2}$ on uterine weight are best explained by the stimulation of the IGF-I gene (7,
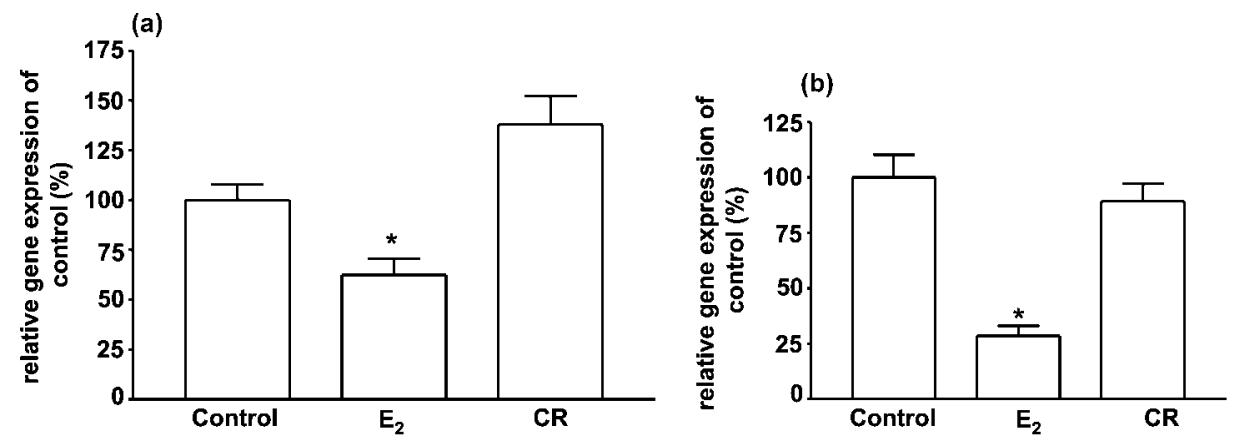

(c)
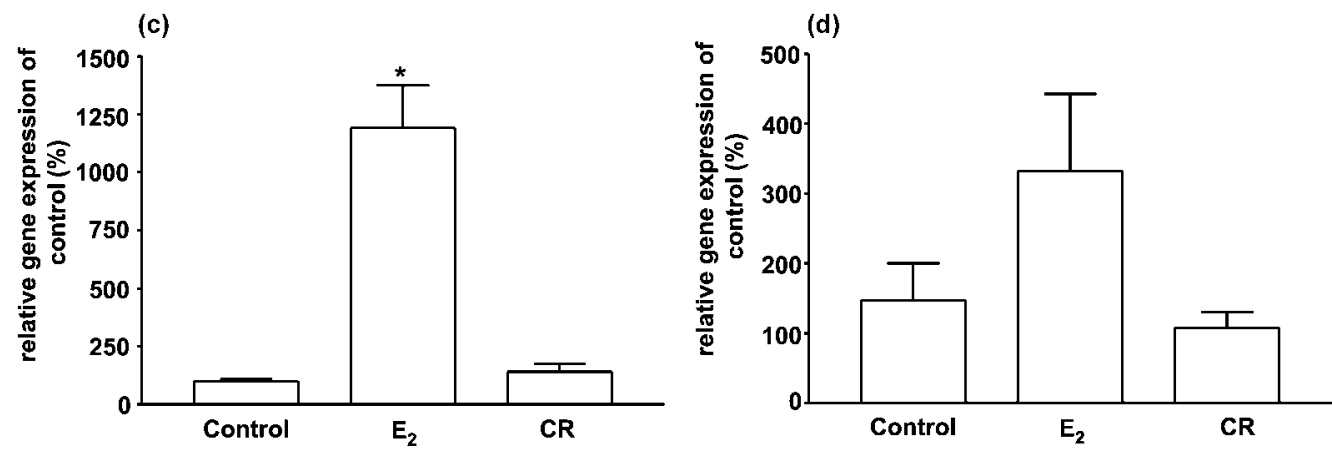

Figure 3 Effects of $E_{2}$, the $C R$ extract and the solvent on expression of various uterine genes $6 \mathrm{~h}$ after i.v. injection of the compounds. (a) While $E_{2}$ significantly reduced $E R \alpha$ gene expression, the $C R$ extract had no significant effect on this gene. (b) $E_{2}$ largely inhibited ERß gene expression, an effect not seen for the CR extract. Gene expression of (c) IGF-I and (d) C3 was stimulated by $E_{2}$ while no effects were observed under the $\mathrm{CR}$ treatment. ${ }^{*} P<0.05$ vs control. 
(a)

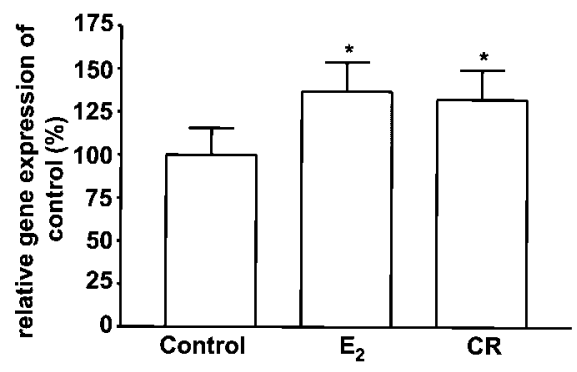

(b)

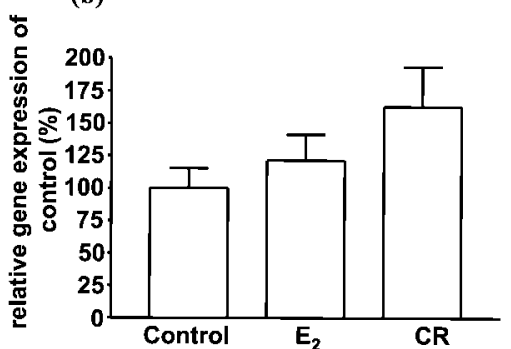

(c)

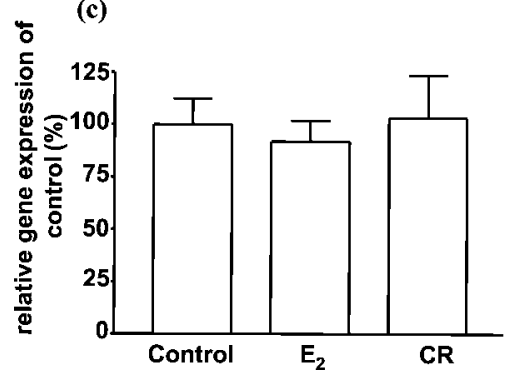

(d)

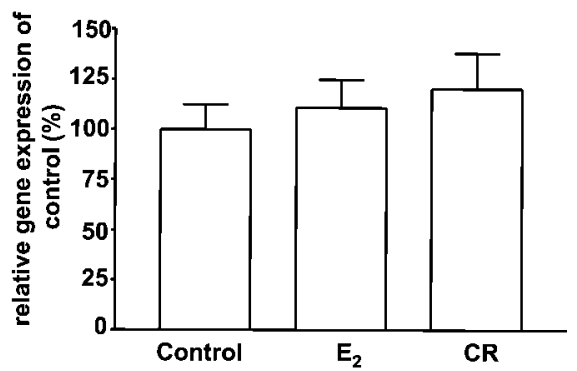

(e)

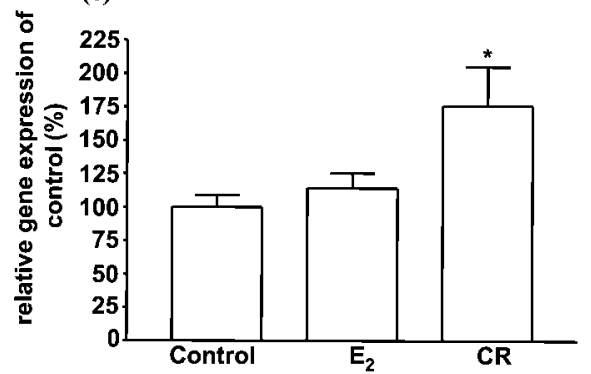

Figure 4 An acute injection of $E_{2}$ or CR extract had a significant stimulatory effect on gene expression of IGF-I in (a) the metaphysis of the femur, while expression of (c) OPG and (d) OC genes was unaffected. An acute stimulation of (b) collagen-1 1 (Col $1 \alpha 1)$ and (e) TRAP was seen after the injection of the $\mathrm{CR}$ extract, an effect also seen following $\mathrm{E}_{2}$ injection. ${ }^{\star} P<0.05$ vs control.

8). IGF-I is a growth factor which causes proliferation of both the endometrium and the myometrium. The initial acute stimulatory effect of $E_{2}$ on uterine weights cannot, most likely, be attributed to proliferation but to increased vascular endothelial growth factor (VEGF) action. VEGF was formerly also called the permeability factor because it causes increased capillary permeability thereby soaking the interstitial endo- (a)

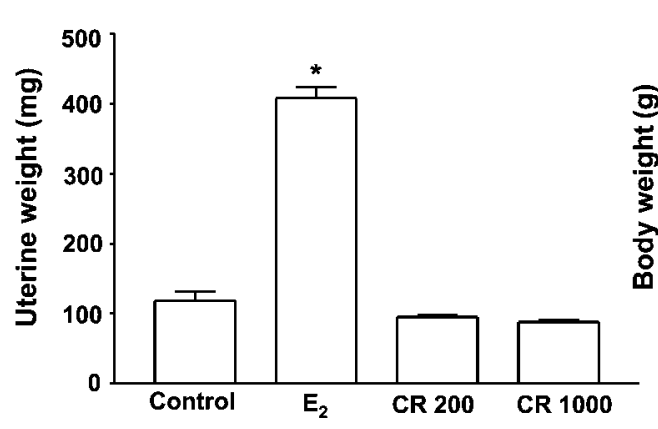

(b)

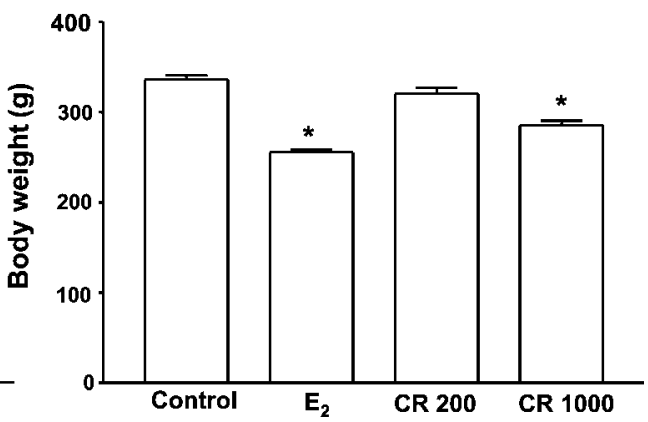

Figure 5 Chronic treatment of ovariectomized rats with $\mathrm{E}_{2}$ or the $\mathrm{CR}$ extract over a period of 3 months (the compounds were applied through phytoestrogen-free pelleted food) yielded a strong stimulatory effect of $E_{2}$ on uterine weight, (a) an effect not observed under two doses of the $C R$ extract (b) while the $E_{2}$ and the $C R$ administration at a higher dose significantly reduced the bodyweight of the animals. ${ }^{\star} P<0.05$ vs control. 


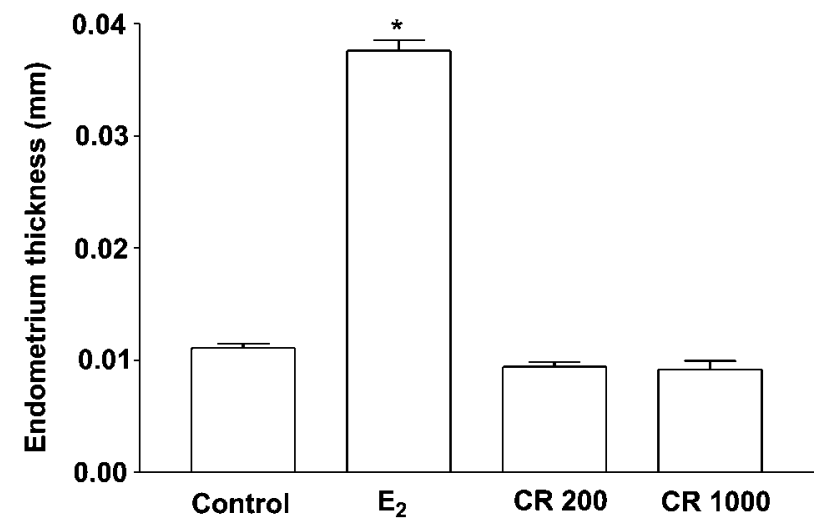

Figure 6 The chronic application of $E_{2}$ but not of the $C R$ extract over 3 months with the food stimulated the thickness of the endometrial epithelium significantly. ${ }^{\star} P<0.05$ vs control. metrial and myometrial tissue and filling the uterine lumen with a serum ultrafiltrate $(7,35)$. The uteri of the chronically $E_{2}$-treated animals were solid streaks with hypertrophied endometrial and myometrial tissue which was most likely due to increased IGF-I action. The complement protein C3 has as yet unknown functions in the uterus but has been demonstrated in numerous experiments to be highly sensitively upregulated by $\mathrm{E}_{2}$. It was therefore not surprising to see largely elevated $\mathrm{C} 3$ gene expression in the acutely and chronically $\mathrm{E}_{2}$-treated animals but even this sensitive parameter did not indicate any estrogenic activity in the $\mathrm{CR}$ extracts as neither dose had any effect on gene expression of $\mathrm{C} 3$. It was interesting to observe an acute and a chronic inhibitory effect of $E_{2}$ on $\mathrm{ER} \beta$ but not on $\mathrm{ER} \alpha$ gene expression. Gustafsson et al. $(6,27,36)$ claim that $\mathrm{ER} \alpha$ may mediate proliferative and $\mathrm{ER} \beta$ differentiational effects (so-called Yin-Yang theory). If this is (a)
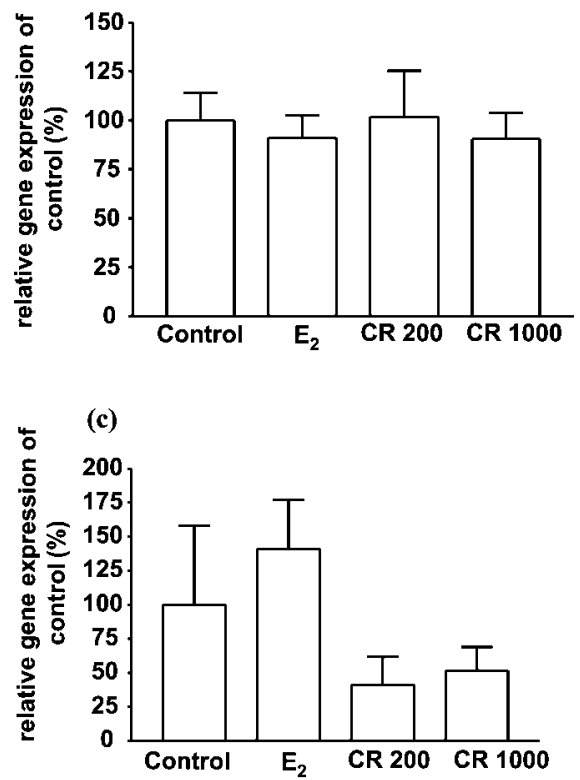

(e)

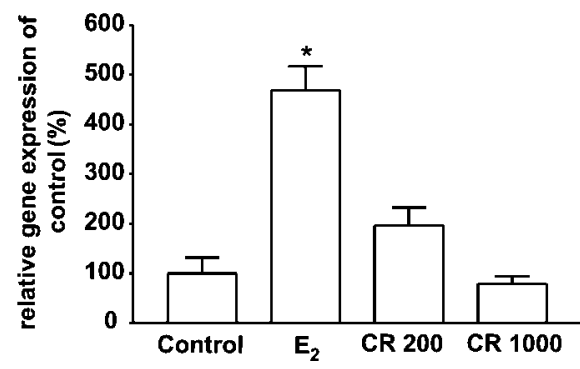

(b)

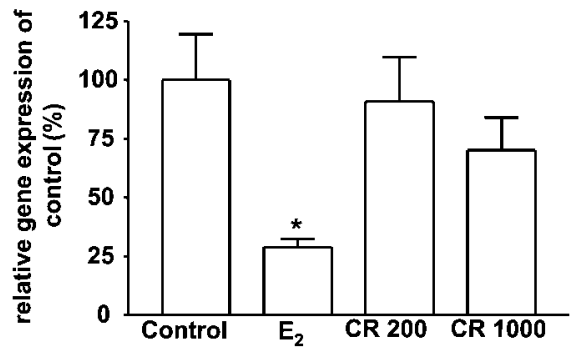

(d)

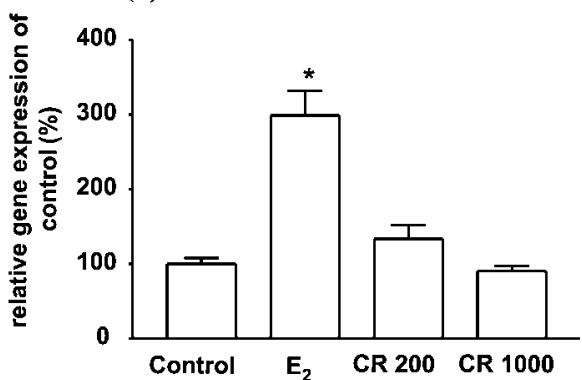

Figure 7 A chronic treatment with $\mathrm{E}_{2}$ had no significant effect on uterine gene expression of (a) ER $\alpha$ and (c) PR but inhibited gene expression of (b) ER $\beta$ and stimulated gene expression of (d) IGF-I and (e) C3. None of these parameters was significantly affected by the two doses of the CR extract. ${ }^{*} P<0.01$ vs control. 
(a)

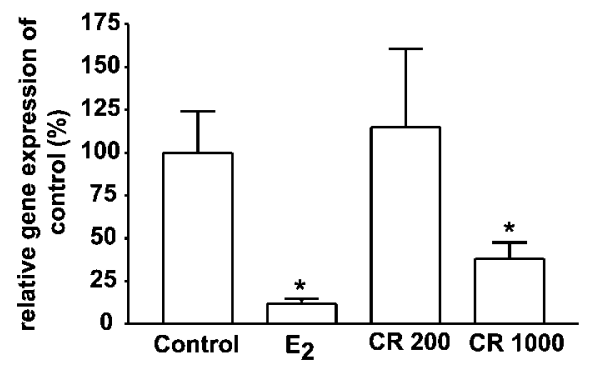

(c)

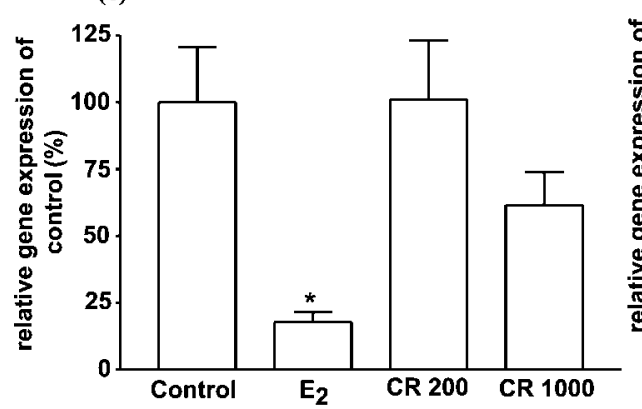

(b)

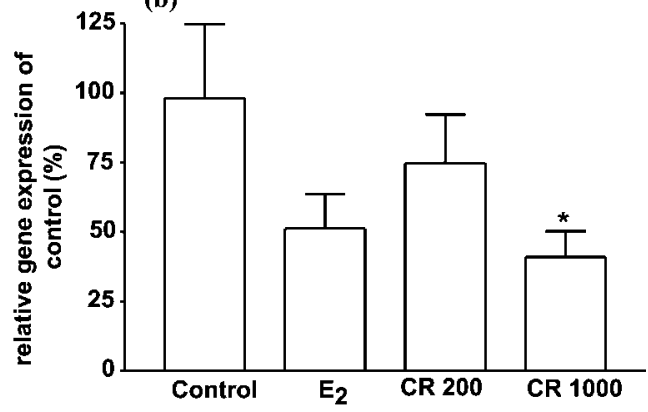

(d)

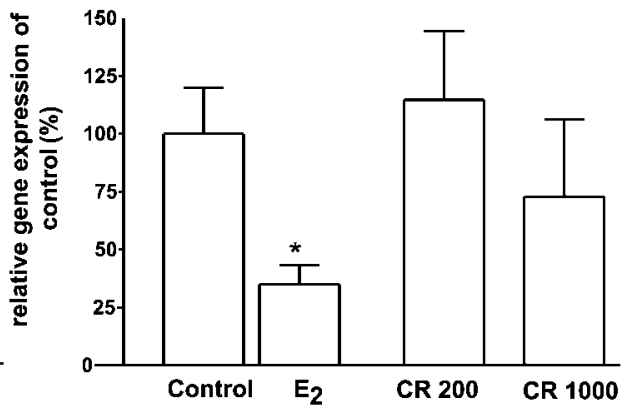

Figure 8 Chronic $E_{2}$ treatment suppressed gene expression of (a) collagen-1 $\alpha 1$, (d) TRAP and (c) OC in the metaphysis of the femur significantly and (b) that of OPG though this effect was not statistically significant after 3 months of treatment. The high dose of CR (1000) also suppressed collagen-1 $\alpha 1$ and OPG gene expression significantly. Expression of the TRAP and OC genes was also suppressed under the high CR dose; this effect, however, was not statistically significant. ${ }^{*} P<0.05$ vs control.

true, the downregulation of ER $\beta$ by $E_{2}$ would allow or enhance the effect of $E_{2}$ via $E R \alpha$ to stimulate uterine parameters involved in ballooning and growth. Indeed, ER $\alpha$ knock-out mice do not show uterine bal-

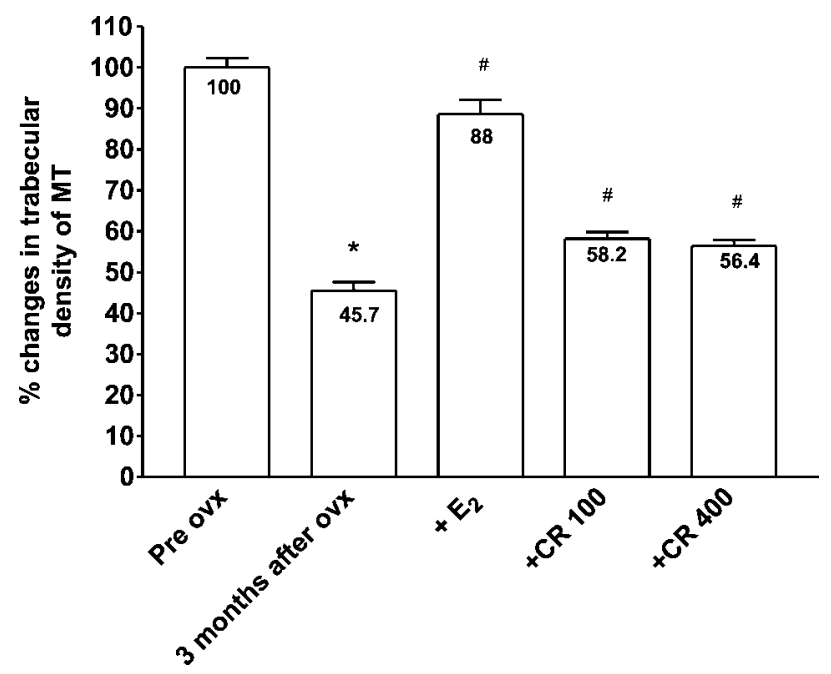

Figure 9 Trabecular density of the metaphysis of the tibia (MT) was reduced by more than $54 \%$ within 3 months after ovariectomy (ovx). This effect was significantly counteracted by $E_{2}$ and to a lesser extent (but also significantly) by CR supplementation to the pelleted food. ${ }^{\star} P<0.05$ vs trabecular density prior to ovariectomy. $\# P<0.05$ vs sham-fed controls (3 months after ovariectomy). looning or proliferation in response to $E_{2}$ (1). This allows the conclusion that compounds in the CR extract do not address the ER of the $\alpha$-subtype.

CT (24) of the metaphysis of the tibia revealed a dramatic loss of bone mass in the ovariectomized animals of more than $50 \%$ of the trabecular structures over 3

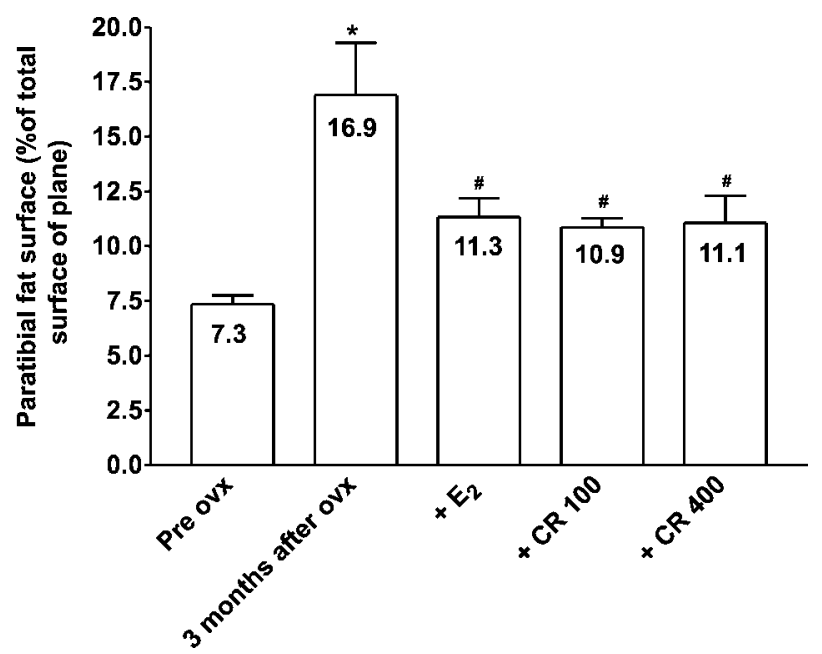

Figure 10 Size of the paratibial fat depots in the variously treated animals. Note that the size was largest in the ovariectomized (ovx) controls and significantly smaller in the $E_{2}$-treated and in the CR BNO 1055-fed rats. ${ }^{*} P<0.05$ vs preovariectomy, $\# P<0.05$ vs sham-fed controls ( 3 months after ovariectomy). 
months. This bone loss was totally prevented by $E_{2}$ and significantly reduced in the animals receiving CR-substituted food. In our experiments, the metaphysis of the femur of rats expressed only ER $\alpha$ and no ER $\beta$. This is in agreement with some, but in disagreement with the results of others $(10-14,37,38)$. Most ER studies were performed in osteosarcoma cell lines, which are dedifferentiated into an embryonic state $(13,14,36$, $37)$ or in bones of immature rats or individuals with healing fractures or various bone diseases (11). Indeed, in developing bones our quantitative real-time RT-PCR system picks up ER $\beta$ mRNA readily (authors' unpublished data). Few publications indicate the presence of ER $\beta$ in the bone of adult rats or mice $(10,37$, 38). If $\mathrm{ER} \beta$ are present in adult bones their number is extremely low. Lim et al. (12) demonstrated $0.7 \times 10^{2}$ copies of ER $\beta$ but $2 \times 10^{5}$ copies of ER $\alpha$ in $1 \mu \mathrm{g}$ RNA.

Utilizing our RT-PCR system we have demonstrated the presence of estrogen-regulated ER $\beta$ mRNA in the uterus. Hence our method picks up ER $\beta$ in other organs but not in the metaphysis of the femur. It is interesting that ER $\beta$ protein is readily detectable in both osteoblasts and osteoclasts (13) which may point to an extremely high translational efficiency of ER $\beta$ mRNA in these bone cells.

$\mathrm{E}_{2}$ had a clear osteoporosis-preventing effect, which appears to be mediated via the amply expressed ER $\alpha$. Since the CR extract, however, also had osteoprotective effects it is unlikely that this osteoprotective effect of CR is mediated via the ER $\alpha$ because the CR extract should then also have uterine effects which were not observed. Hence, the receptor type involved in mediating the osteprotective effects of $\mathrm{CR}$ remains obscure at present. Possibly splice variants of ER $\alpha$ or ER $\beta$ which are not present in the uterus and which are not picked up by our PCR are mediating the estrogenic effects of CR. Alternatively, another, not yet cloned ER or another estrogen-binding protein which affects transcriptional efficiency of $\mathrm{ER} \alpha$ may be involved.

It is known that many of the estrogenic effects in the bone are exerted via IGF (39-41). It was therefore not surprising to observe a slight acute stimulatory effect of $E_{2}$ on IGF-I gene expression. Estradiol appears also to activate directly (via an ERE) or indirectly (via paracrine mechanisms) collagen- $1 \alpha 1$, OC and OPG gene expression. The TRAP was also rapidly activated within $6 \mathrm{~h}$ after $\mathrm{E}_{2}$ treatment. Hence, not only osteoblast but also osteoclast activities are acutely upregulated by $\mathrm{E}_{2}$ and this effect was in part shared by the higher dose of the CR extract.

The observation that in the chronically $E_{2}$-treated rats all acutely $E_{2}$-upregulated osteoblast parameters were downregulated below control values was not surprising because osteoclast activity was also reduced. Both bone-forming compartments appear to be highly active in estrogen-deprived animals with osteoclasts being the dominant compartment. Hence, bone turnover is increased with bone degradation being higher than bone formation which results in osteoporosis $(42,43)$. In response to $E_{2}$ treatment after the above-detailed acute stimulation of both compartments, osteoblast and osteoclast activity appeared to be decreased which results in an equilibrated low bone turnover. Similar mechanisms appear to take place in the metaphysis of the femur of the CR-treated animals as the expression of the estrogen-regulated genes are qualitatively similarly affected in the CR-treated animals. Quantitatively, the effects, however, are smaller. This reflects also in the loss of bone mineral density. In the $E_{2}$-substituted ovariectomized rats, loss of trabecular bone density of the metaphysis of the tibia as determined by quantitative CT was almost negligible in comparison with the pretreatment values. Such an anti-osteoporotic effect was also clearly present in the CR-treated animals although not as profound as in the $E_{2}$-treated rats. However, significantly less bone was lost in comparison with the control animals.

In the same CT plane in which the metaphysis of the tibia is located, a small fat depot is visible, the size of which could be quantified. In good agreement with the generally increased bodyweight of the ovariectomized animals, this fat depot increased in size during the 3 months following ovariectomy. In the $\mathrm{E}_{2}$-treated animals, this effect was almost as small as prior to ovariectomy and was partially shared by the two doses of the CR extract in a dose-dependent manner. Hence, the putative phytoestrogens present in the CR extract did not only exert an estrogenic and therefore osteoprotective effect in the bone but it had also an estrogenic effect on the total bodyweight and this appears to be due to a reduced fat accumulation which had occurred in the ovariectomized control-fed animals. Hence, these substances may have anti-lipotropic or lipolytic effects.

The chemical identity of the estrogenic substance(s) in the CR extract BNO 1055 deserves some discussion. Earlier we had shown that another CR isopropanolic extract contained small amounts of formononitin (44). Later, extracts produced by the same extraction procedure were devoid of this isoflavone (45) but recently another group purified fukinolic acid out of a CR extract which had estrogenic effects (46). In the extract used for the present experiments no attempt was made to purify the estrogenic compound(s). In a recent double-blind, placebo and conjugated estrogen controlled clinical study, however, the CR extract BNO 1055 proved to have SERM activities as major climacteric complaints and bone turnover parameters as measured in the serum (crosslaps, bone-specific alkaline phosphatase, OC) were influenced as in the patients receiving conjugated estrogens (47).

In summary, we have demonstrated that the CR extract BNO 1055 contains as yet unidentified substances which have estrogenic effects in the hypothalamo/pituitary axis to reduce pituitary LH secretion and 
in the bone to partially prevent osteoporosis. The CR extract BNO 1055, however, was devoid of estrogenic activities in the uterus. From these results we have concluded that in the CR extract BNO 1055 estrogenic compounds are present which have SERM activities with desirable effects in the hypothalamo/pituitary unit and in the bone but with no undesirable effects in the uterus.

\section{Acknowledgements}

This work was supported by the European Commission (EUROSTERONE contract no. QLRT-1990-00762 and (E)UROESTROGEN(E)S contract no. QLK6-CT-200000565).

\section{References}

1 Couse JF \& Korach KS. Estrogen receptor null mice: what have we learned and where will they lead us? Endocrine Reviews 199920 358-417.

2 Düker E-M, Kopanski L, Jarry H \& Wuttke W. Effects of extracts from Cimicifuga racemosa on gonadotropin release in menopausal women and ovariectomized rats. Planta Medica $1991 \quad 57$ 420-424.

3 Cosman F \& Lindsay R. Selective estrogen receptor modulators: clinical spectrum. Endocrine Reviews 199920 418-434.

4 Knobil E. Neuroendocrine control of the menstrual cycle. Recent Proceedings in Hormone Research 198036 53-88.

5 Tataryn IV, Meldrum DR, Lu KH, Frumar AM \& Judd HL. LH, FSH and skin temperature during the menopausal hot flash. Journal of Clinical Endocrinology and Metabolism 197949 152-154.

6 Weihua Z, Saji S, Mäkinen S, Cheng G, Jensen EV, Warner M et al. Estrogen receptor (ER) $\beta$, a modulator of $E R \alpha$ in the uterus. PNAS $2000975936-5941$.

7 Klotz DM, Hewitt SC, Ciana P, Raviscioni M, Lindzey JK, Foley J et al. Requirement of estrogen receptor-alpha in insulin-like growth factor-1 (IGF-1)-induced uterine responses and in vivo evidence for IGF-1/estrogen receptor cross-talk. Journal of Biological Chemistry 2002277 8531-8537.

8 Adesanya OO, Zhou J, Samathanam C, Powell-Braxton L \& Bondy CA. Insulin-like growth factor 1 is required for $\mathrm{G}_{2}$ progression in the estradiol-induced mitotic cycle. PNAS $1999 \mathbf{9 6}$ 3287-3291.

9 Diel P, Schulz T, Smolnikar K, Strunck E, Vollmer G \& Michna H. Ability of xeno- and phytoestrogens to modulate expression of estrogen-sensitive genes in rat uterus: estrogenicity profiles and uterotropic activity. Journal of Steroid Biochemistry and Molecular Biology 200073 1-10.

10 Onoe Y, Miyaura C, Ohta H, Nozawa S \& Suda T. Expression of estrogen receptor beta in rat bone. Endocrinology 1997138 4509-4512.

11 Windahl SH, Norgard M, Kuiper GG, Gustafsson JA \& Andersson G. Cellular distribution of estrogen receptor beta in neonatal rat bone. Bone 200026 117-121.

12 Lim SK, Won YJ, Lee HC, Huh KB \& Park YS. A PCR analysis of $\mathrm{ER} \alpha$ mRNA abundance in rats and the effect of ovariectomy. Journal of Bone and Mineral Research 199914 1189-1196.

13 Waters KM, Rickard DJ, Riggs BL, Khosla S, Katzenellenbogen JA, Katzenellenbogen BS et al. Estrogen regulation of human osteoblast function is determined by the stage of differentiation and the estrogen receptor isoform. Journal of Cell Biochemistry 2001 83 448-462.

14 Collier FM, Huang WH, Holloway WR, Hodge JM, Gillespie MT, Daniels LL et al. Osteoclasts from human giant cell tumors of bone lack estrogen receptors. Endocrinology $1998 \quad 139$ $1258-1267$

15 Windahl SH, Hollberg K, Vidal O, Gustafsson JA, Ohlsson C \& Andersson G. Female estrogen receptor $\beta-/-$ mice are partially protected against age-related trabecular bone loss. Journal of Bone and Mineral Research $2001161388-1398$.

16 Windahl SH, Vidal O, Andersson G, Gustafsson JA \& Ohlsson C. Increased cortical bone mineral content but unchanged trabecular bone mineral density in female ER $\beta-/-$ mice. Journal of Clinical Investigation $1999 \mathbf{1 0 4} 895-901$.

17 Simonet WS, Lacey DL, Dunstan CR, Kelley M, Chang MS, Lüthy R et al. Osteoprotegerin: a novel secreted protein involved in the regulation of bone density. Cell $1997 \mathbf{8 9} 309-319$.

18 Hsu H, Lacey DL, Dunstan CR, Solovyev I, Colombero A, Timms E et al. Tumor necrosis factor receptor family member RANK mediates osteoclast differentiation and activation induced by osteoprotegerin ligand. PNAS 199996 3540-3545.

19 Lacey DL, Timms E, Tan HL, Kelley MJ, Dunstan CR, Burgess T et al. Osteoprotegerin ligand is a cytokine that regulates osteoclast differentiation and activation. Cell $199893165-176$.

20 Hofbauer LC \& Heufelder AE. Osteoprotegerin and its cognate ligand: a new paradigm of osteoclastogenesis. European Journal of Endocrinology $1998139152-154$.

21 Danielsen CC \& Flyvbjerg A. Insulin-like growth factor I as a predictor of cortical bone mass in a long term study of ovariectomized and estrogen-treated rats. Bone 199619 493-498.

22 Verhaeghe J, van Bree R, Van Herck E, Thomas H, Skottner A, Dequeker $\mathrm{J}$ et al. Effects of recombinant human growth hormone and insulin-like growth factor-I, with or without 17 beta-estradiol, on bone and mineral homeostasis of aged ovariectomized rats. Journal of Bone and Mineral Research 199611 $1723-1735$.

23 Shinoda M, Latour MG \& Lavoie JM. Effects of physical training on body composition and organ weights in ovariectomized and hyperestrogenic rats. International Journal of Obesity Related Metabolic Disorders 200226 335-343.

24 Helterbrand JD, Higgs RE Jr, Iversen PW, Tysarczyk-Niemeyer G \& Sato M. Application of automatic image segmentation to tibiae and vertebrae from ovariectomized rats. Bone $1997 \mathbf{2 1}$ 401-409.

25 Heid CA, Stevens J, Livak KJ \& Williams PM. Real time quantitative PCR. Genome Research 19966 986-994.

26 Spereafico E, Bettini E, Pollio G \& Maggi A. Nucleotide sequence of estrogen receptor cDNA from Sprague-Dawley rat. European Journal of Pharmacology 1992227 353-356.

27 Kuiper GG, Enmark E, Pelto-Huikko M, Nilsson S \& Gustafsson JA. Cloning of a novel receptor expressed in rat prostate and ovary. PNAS 199693 5925-5930.

28 Park-Sarge OK \& Mayo KE. Regulation of the progesterone receptor gene by gonadotropins and cyclic adenosin $3^{\prime}, 5^{\prime}$-monophosphate in rat granulosa cells. Endocrinology $1994 \mathbf{1 3 4}$ 709-718.

29 Conn G, Bayne ML, Soderman DD, Kwok PW, Sullivan KA, Palisi TM et al. Amino acid and cDNA sequences of a vascular endothelial cell mitogen that is homologous to platelet-derived growth factor. PNAS $1990 \mathbf{8 7} 2628-2632$.

30 Misumi Y, Sohda M \& Ikehara Y. Nucleotide and deduced amino acid sequence of rat complement C3. Nucleic Acids Research 1990182178.

31 Brandsten C, Lundmark C, Christersson C, Hammarstrom L \& Wurtz T. Expression of collagen alpha1(I) mRNA variants during tooth and bone formation in the rat. Journal of Dental Research 199978 11-19.

32 Pan LC \& Price PA. The propeptide of rat bone gammacarboxyglutamic acid protein shares homology with other vitamin K-dependent protein precursors. PNAS $1985 \quad \mathbf{8 2}$ $6109-6113$

33 Ek-Rylander B, Bill P, Norgaad M, Nilsson S \& Andersson G. Cloning, sequence, and developmental expression of a type 5 , 
tartrate-resistant, acid phosphatase of rat bone. Journal of Biological Chemistry $199126624684-24689$.

34 Jarry H, Gorkow CH \& Wuttke W. Treatment of menopausal symptoms with extracts of Cimicifuga racemosa: in vivo and in vitro evidence for estrogenic activity. In Phytopharmaka in Forschung und klinischer Anwendung, pp 99-112. Eds D Loew \& N Rietbrock. Darmstadt: Steinkopff, 1995.

35 Cullinan-Bove K \& Koos RD. Vascular endothelial growth factor/ vascular permeability factor expression in the rat uterus: rapid stimulation by estrogen correlates with estrogen-induced increases in uterine capillary permeability and growth. Endocrinology $199313829-837$.

36 Mäkelä S, Savolainen H, Aavik E, Myllärniemi M, Strauss L, Taskinen E et al. Differentiation between vasculoprotective and uterotrophic effects of ligands with different binding affinities to estrogen receptors $\alpha$ and $\beta$. PNAS 199996 7077-7082.

37 Gruber R, Czerwenka K, Wolf F, Ho G-M, Willheim M \& Peterlik M. Expression of the vitamin $\mathrm{D}$ receptor, of estrogen and thyroid hormone receptor $\alpha$ - and $\beta$-isoforms, and of the androgen receptor in cultures of native mouse bone marrow and of stromal/ osteoblastic cells. Bone 199924 465-473.

38 Lindberg MK, Alatalo SL, Halleen JM, Mohan S, Gustafsson JA \& Ohlsson C. Estrogen receptor specificity in the regulation of the skeleton in female mice. Journal of Endocrinology $2001 \mathbf{1 7 1}$ 229-236.

39 Wakisaka A, Tanaka H, Barnes J \& Liang CT. Effect of locally infused IGF-I on femoral gene expression and bone turnover activity in old rats. Journal of Bone and Mineral Research 1998 13 13-19.

40 Bikle DD, Harris J, Halloran BP, Roberts CT, Leroith D \& Morey-Holton E. Expression of the genes for insulin-like growth factors and their receptors in bone during skeletal growth. American Journal of Physiology 1994267 E278-E286.
41 Kassem M, Okazaki R, Harris SA, Spelsberg TC, Conover CA \& Riggs BL. Estrogen effects on insulin-like growth factor gene expression in a human osteoblastic cell line with high levels of estrogen receptor. Calcified Tissue International $1998 \mathbf{6 2}$ 60-66.

42 Wronski TJ, Contrón M \& Dann LM. Temporal relationship between bone loss and increased bone turnover in ovariectomized rats. Calcified Tissue International 198843 179-183.

43 Turner RT, Vandersteenhoven JJ \& Bell NH. The effects of ovariectomy and $17 \beta$-estradiol on cortical bone histomorphometry in growing rats. Journal of Bone and Mineral Research 19872 115-122.

44 Jarry H \& Harnischfeger G. Studies on the endocrine effects of the contents of Cimicifuga racemosa: 1 . Influence on the serum concentration of pituitary hormones in ovariectomized rats. Planta Medica $1985 \mathbf{5 1} 46-49$.

45 Struck D, Tegtmeier M \& Harnischfeger G. Flavones in extracts of Cimicifuga racemosa. Planta Medica 199763289.

46 Kruse SO, Loehning A, Pauli GF, Winterhoff H \& Nahrstedt A. Fukinic and piscidic acid esters from the rhizome of Cimicifuga racemosa and the in vitro estrogenic activity of fukinolic acid. Planta Medica 199965 763-764.

47 Wuttke W, Seidlová-Wuttke D, Gorkow C \& März R. The Cimicifuga preparation BNO 1055 vs. conjugated estrogens and placebo in a double-blind placebo controlled study: effects on menopause symptoms and bone markers. Maturitas $2003 \mathbf{4 4}$ $67-77$.

Received 20 February 2003

Accepted 27 June 2003 